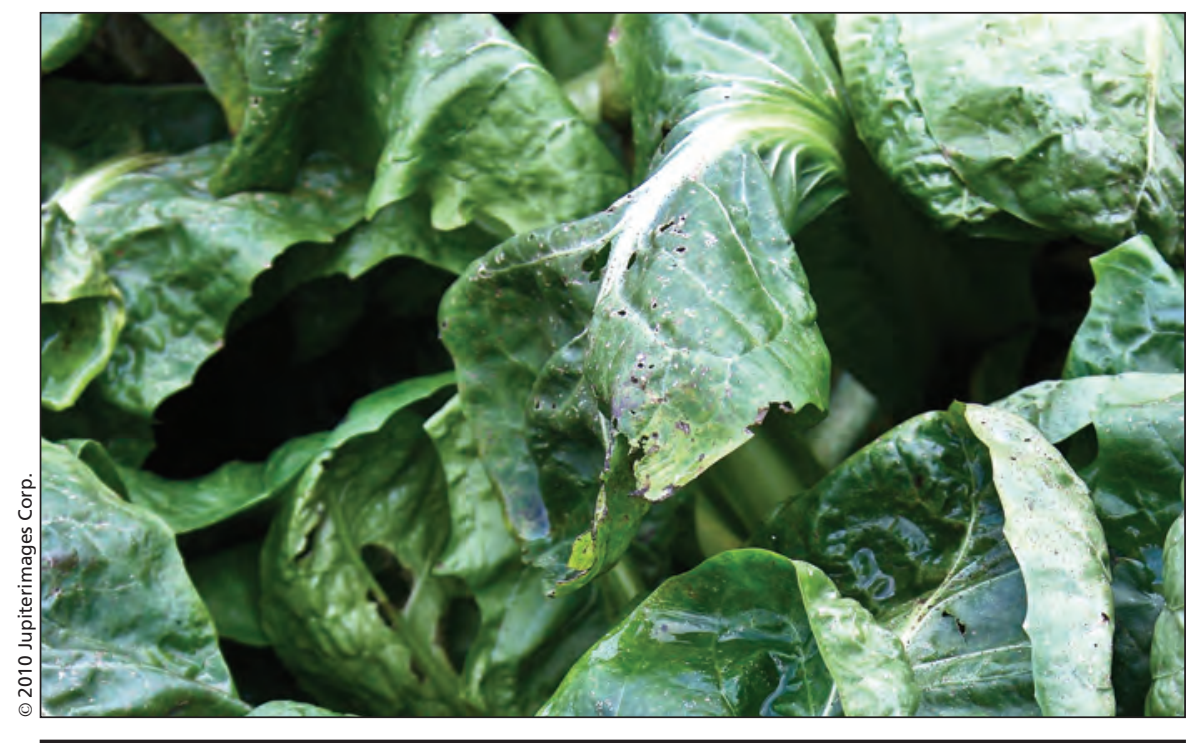

In 2006, Escherichia coli 0157:H7 found in raw spinach in the United States was linked to about 200 illnesses and several deaths.

role in food safety are working together.

Obama issued a statement on July 7 supporting action on the Senate legislation, which he said would complement the efforts of the working group. He said the administration already has taken steps to reduce the prevalence of $E$. coli, implemented new standards to reduce exposure to campylobacter, one of the most common causes of food poisoning, and issued a rule to help control salmonella contamination, the most common cause.

Attorney Bill Marler, whose Seattle law firm specializes in food-related illnesses, says a lack of coordination among state, federal and local governments is one reason that outbreaks of foodborne illnesses aren't identified more quickly.

FDA is "underfunded and understaffed for what we expect them to do and it's only getting worse" as imports increase and food production becomes more complex, Marler says. "The risks are just larger. We've not kept up with the reality of how our food is produced."

Consumer groups, meanwhile, have been trying to increase pressure on Congress to act by stressing public interest in the issue.
Sandra Eskin, director of the Pew Health Group's food safety campaign, says people are shocked to learn the FDA doesn't have authority under 70year-old food safety laws to require recalls, and that food facilities can go a decade between FDA inspections.

Make Our Food Safe, a coalition of consumer, public health and food safety groups, welcomed the committee's recommendation that the FDA be given more authority. It said in a statement that the FDA "desperately needs a specific mandate to prevent foodborne illness rather than continuing to act only after people become sick or die."

The coalition has an ally in Robyn Allgood of Idaho, whose two-year-old son Kyle died in 2006 from eating a spinach smoothie contaminated with E. coli. Allgood recently taped a radio ad urging senators to act on the legislation, and travelled to Washington to press for action.

"No family should have to go through this," Allgood says in the radio ad, paid for by the Pew Charitable Trust. "We can save other children."

The Institute of Medicine and National Research Council are private, nonprofit institutions that provide advice to Congress, which requested the food safety report. - Nancy Benac, Washington, DC

DOI: $10.1503 / \mathrm{cmaj} .109-3317$

\title{
Gulf oil spill exposes gaps in public health knowledge
}

Previously published at www.cmaj.ca

$\mathrm{T}$ he Gulf of Mexico oil spill set in motion an army of health professionals deployed by Washington, states and centres of medical learning, all dedicated to helping Americans stay well in the throes of the catastrophe and its aftermath.

For all that effort, an unsettling reality sank in even before the undersea rupture was staunched: Science knows precious little about the human hazards of exposure to crude oil. Researchers have a better understanding of oil's per- ils for pelicans and marshlands of the Louisiana bayou.

In the short term, the health effects have been most obvious among the thousands of workers scrambling to contain and now clean up the spill. They've worked in brutal heat for months, face to face with the primal sludge, in conditions too steamy for many to wear full protective gear. They've experienced respiratory problems, skin irritation and plenty of heat stress.

Much less clear is the impact the chemical cocktail in Gulf crude will have on the public in years to come.
Gulf states have now become a living laboratory as teams of medical professionals lay the foundation for long-term monitoring of the population.

At congressional hearings in Washington, DC, and an Institute of Medicine conference convened in New Orleans, Louisiana, as the oil still flowed, experts expressed frustration that they know little about the health risks of a substance that courses so ubiquitously through daily life.

"While extensive data exists on the effects of oil spills on wildlife and ecosystems, the effects on human health 
from these exposures have not been well studied," Dr. Aubrey Miller, senior medical adviser to the National Institute of Environmental Health Sciences and the National Toxicology Program, told Congress.

Says Dr. Lynn R. Goldman of the Johns Hopkins Bloomberg School of Public Health in Baltimore, Maryland: "This disaster is bigger than anyone could have predicted and no governmental agency anywhere in the world has been prepared to address health surveillance and monitoring."

Of nearly 40 sizable oil spills in recent decades, most from supertanker breaches, only seven were subjected to epidemiological studies of any import. One of those, the infamous 1989 Exxon Valdez disaster in Alaska, was examined primarily for its psychosocial effects. Vagaries in geography, oil type and circumstance have made comparisons with the Gulf spill of limited use.

Miller's agency is recruiting a cohort of up to 20000 spill workers and Gulf residents, backed by an initial US $\$ 10$ million from the National Institutes of Health, to study their medical history, oil exposure and future immunological, neurobehavioral and respiratory health.

Much rides on what is found. Unlike in the Exxon Valdez aftermath, when recovery payments stretched out over decades of litigation and awards ultimately were slashed by the US Supreme Court, BP LLC agreed to set up a US\$2-billion fund for Gulf residents, businesses and the environment. Physical ailments now and in the future qualify for compensation.

Mental health suffering, however, an inevitable consequence of the disaster, yet one that is difficult to quantify, might be frozen out of the fund. Kenneth Feinberg, the blunt independent arbiter of the fund, says mental health might be a step too far.

"If you start compensating purely mental anguish without a physical injury," he told legislators, "we'll be getting millions of claims from people watching television. You have to draw the line somewhere."

Grounded fishermen, owners and employees of shuttered businesses and other residents close to the crisis have

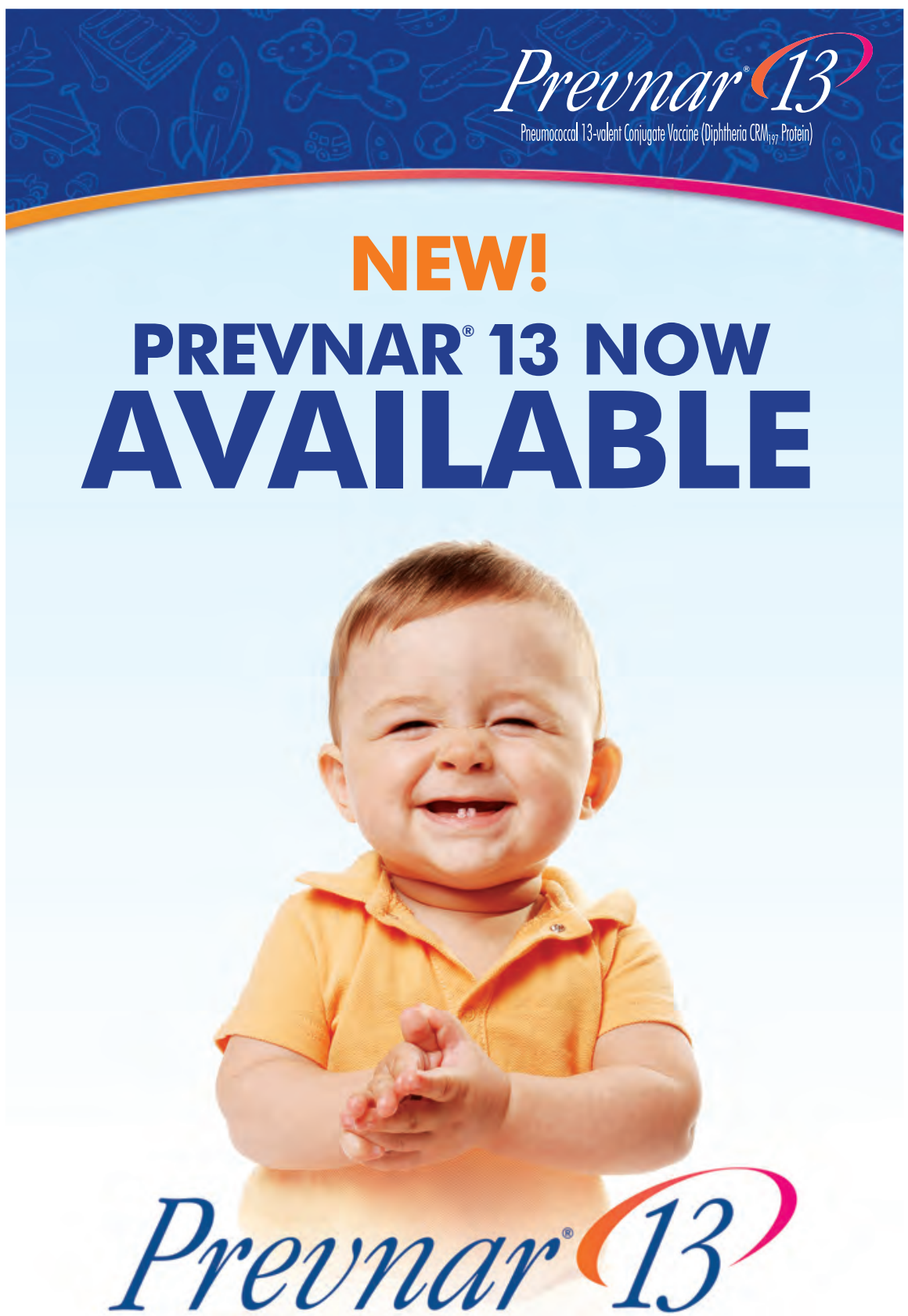

Prevnar 13 is indicated for the active immunization against Streptococcus pneumoniae serotypes $1,3,4,5,6 \mathrm{~A}, 6 \mathrm{~B}, 7 \mathrm{~F}, 9 \mathrm{~V}, 14,18 \mathrm{C}, 19 \mathrm{~A}, 19 \mathrm{~F}$ and $23 \mathrm{~F}$ causing invasive pneumococcal disease, including:

- Sepsis, meningitis, bacteraemic pneumonia, pleural empyema and bacteraemia

- Indicated for use in infants and children from 6 weeks through 5 years of age

Wyeth ${ }^{\text {Metaber }}$ RAD

(c) 2010 Wyeth Canada 
been exhibiting signs of acute anxiety, depression, increased and excessive drinking, and suicidal ideation, Louisiana state counselling teams reported.

Those conditions, behaviours and more - domestic violence, post-traumatic stress disorder, broken marriages and community discord - were the legacy of the Exxon Valdez, the worst spill in US history until the Deepwater Horizon drilling rig exploded in the Gulf on April 20, killing 11 crewmen.

The rig's Macando well spewed as much as 700 million litres before a temporary plug finally worked in mid-July. Now, BP is readying a permanent kill.

Researchers at the New Orleans conference heard evidence that cleanup workers in Spain's far smaller 2002 spill, from the sinking of the tanker Prestige, suffered DNA damage, although of a kind that reversed itself.

Dr. John Howard, director of the National Institute for Occupational Safety and Health, told Congress that oil is a skin and lung irritant but over

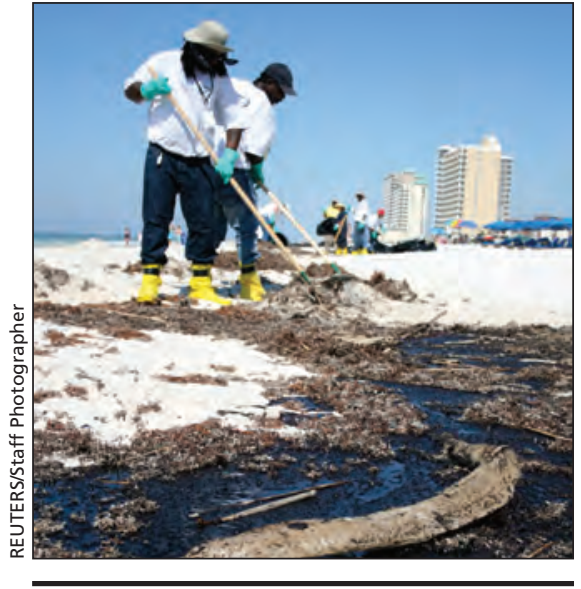

Workers hired to clean up the Gulf oil spill have experienced respiratory problems, skin irritation and heat stress.

the long term, it is "unlikely" to damage health as far as is known.

Still, uncertainties persist, from fumes in the air, tar balls on beaches, chemical dispersants used on the slick, contaminants consumed by sedentary sea life that could not get out of the way, and more.
Children - "low-living, thinskinned, risk-taking humans," as they were called at the New Orleans conference - are of special concern, for they have higher respiratory and metabolic rates than adults, relatively undeveloped immune systems and greater sensitivity to toxins in the atmosphere.

"What might be annoying to an adult could be a real problem for a child, particularly if the child is an infant or toddler who has pre-existing conditions," Howard said.

He joined other top US health policy authorities in testifying to a Senate committee on the health effects of the spill.

"We don't have the world's literature here that's able to tell us what happens when there's this much oil around populated sites," he said. "As we've said all this afternoon, we just really do not know a lot of things here. And the only way to find out is to be able to study." - Cal Woodward, Washington, DC

DOI:10.1503/cmaj.109-3329

\section{More news at www.cmaj.ca}

\begin{abstract}
Decades of water safety training culturally "irrelevant" to First Nation people: Canada's Aboriginal people and others at high risk of drowning are among those least served by conventional water safety training, say injury prevention experts. - Lauren Vogel, CMAJ
\end{abstract}

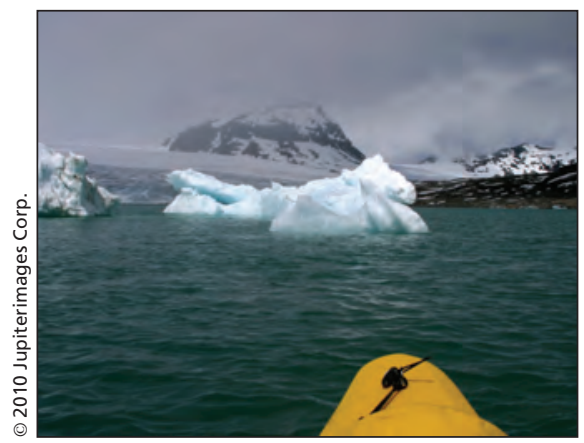

Affluence prompts more women in China to light up: More than $60 \%$ of men, and $4 \%$ of women, in China are smokers, and the latter percentage is set to rise. - Suzanne Ma, Hong Kong, China
Pros and cons of first aid training? Experts appear divided on the quality and quantity of first aid training in Canada. - Elyse Skura, Ottawa, Ont.

Canadian medical schools slow to integrate health informatics into curriculum: Most Canadian medical schools don't include health informatics in their core curriculum. Stephen Strauss, Toronto, Ont.

Cooperative clinics revolutionizing primary care in Nepal: Cooperative clinics are part of a revolution in primary care in Nepal. - Wendy Glauser, Kathmandu, Nepal

Food crisis escalates in Africa's Sahel region: Pleas for humanitarian assistance to help the 10 million people at risk of acute hunger in Africa's Sahel region are gaining urgency as international aid agencies struggle to keep pace with what they're calling one of the worst food crises in years. - Lauren Vogel, CMAJ
FDA hearings leave doctors, patients in limbo on Avandia: Two days of hearings into the safety of a leading type 2 diabetes drug have left doctors and patients in limbo about continuing to prescribe or take the medicine. - Laura Eggertson, Ottawa, Ont., and Cal Woodward, Washington, DC

Expanded use of medical imaging technologies poses challenges: The Canadian health care system faces paralysis unless it improves access to medical imaging, warns the head of the nation's largest medical imaging department. - Becky Rynor, Ottawa, Ont.

'Hodge-podge' regulation of alternative medicine in Canada: As Ontario drafts standards of practice for homeopathy and traditional Chinese medicine, the debate continues across Canada over whether or not it's necessary to regulate complementary and alternative medicine. - Lauren Vogel, CMAJ 